\title{
Clinical effectiveness and cost-effectiveness of pegvisomant for the treatment of acromegaly: a systematic review and economic evaluation
}

\author{
David J Moore*1, Yaser Adi $^{2}$, Martin J Connock ${ }^{1}$ and Sue Bayliss ${ }^{1}$
}

Address: ${ }^{1}$ Public Health, Epidemiology and Biostatistics, School of Health and Population Sciences, University of Birmingham, Birmingham, B15 2TT, UK and ${ }^{2} \mathrm{Health}$ Sciences Research Institute, Warwick Medical School, University of Warwick, Coventry, CV4 7AL, UK

Email: David J Moore* - d.j.moore@bham.ac.uk; Yaser Adi - y.adi@warwick.ac.uk; Martin J Connock - m.j.connock@bham.ac.uk; Sue Bayliss - s.bayliss@bham.ac.uk

* Corresponding author

Published: 8 October 2009

BMC Endocrine Disorders 2009, 9:20 doi:10.1186/1472-6823-9-20

This article is available from: http://www.biomedcentral.com/1472-6823/9/20

(c) 2009 Moore et al; licensee BioMed Central Ltd.

This is an Open Access article distributed under the terms of the Creative Commons Attribution License (http://creativecommons.org/licenses/by/2.0), which permits unrestricted use, distribution, and reproduction in any medium, provided the original work is properly cited.
Received: 5 September 2008

Accepted: 8 October 2009

\begin{abstract}
Background: Acromegaly, an orphan disease usually caused by a benign pituitary tumour, is characterised by hyper-secretion of growth hormone $(\mathrm{GH})$ and insulin-like growth factor I (IGFI). It is associated with reduced life expectancy, cardiovascular problems, a variety of insidiously progressing detrimental symptoms and metabolic malfunction. Treatments include surgery, radiotherapy and pharmacotherapy. Pegvisomant (PEG) is a genetically engineered $\mathrm{GH}$ analogue licensed as a third or fourth line option when other treatments have failed to normalise IGF-I levels.
\end{abstract}

Methods: Evidence about effectiveness and cost-effectiveness of PEG was systematically reviewed. Data were extracted from published studies and used for a narrative synthesis of evidence. A decision analytical economic model was identified and modified to assess the cost-effectiveness of PEG.

Results: One RCT and 17 non-randomised studies were reviewed for effectiveness. PEG substantially reduced and rapidly normalised IGF-I levels in the majority of patients, approximately doubled GH levels, and improved some of the signs and symptoms of the disease. Tumour size was unaffected at least in the short term. PEG had a generally safe adverse event profile but a few patients were withdrawn from treatment because of raised liver enzymes. An economic model was identified and adapted to estimate the lower limit for the cost-effectiveness of PEG treatment versus standard care. Over a 20 year time horizon the incremental cost-effectiveness ratio was $£ 81,000 / Q A L Y$ and $£ 212,000 / L Y G$. To reduce this to $£ 30 \mathrm{~K} / \mathrm{QALY}$ would require a reduction in drug cost by about one third.

Conclusion: PEG is highly effective for improving patients' IGF-I level. Signs and symptoms of disease improve but evidence is lacking about long term effects on improved signs and symptoms of disease, quality of life, patient compliance and safety. Economic evaluation indicated that if current standards (UK) for determining cost-effectiveness of therapies were to be applied to PEG it would be considered not to represent good value for money. 


\section{Background}

Acromegaly is a rare endocrine disorder resulting from excessive secretion of growth hormone (GH) [1,2]. The underlying cause in more than $90 \%$ of patients is a benign adenoma of the GH-secreting cells of the anterior pituitary. Very rarely acromegaly is due to hypothalamic over secretion of growth hormone releasing hormone (GHRH) or to extra-pituitary tumours that secrete GH or GHRH.

GH promotes insulin-like growth factor-1 (IGF-1) secretion. Prolonged exposure to elevated endogenous levels of GH and/or IGF-1 in acromegaly results in excessive somatic growth and metabolic dysfunction leading to both direct and indirect tissue damage, secondary systemic illness and reduced life expectancy. Extended discussion of the systemic complications can be found in Colao et al 2004 [3], Melmed 2006 [1] and Chanson and Salenave[2]

The insidious development of symptoms and their variety contribute to delayed diagnosis of about 8 years from onset of first symptoms [4]. Biochemical diagnosis is made by immunoassay of GH and of IGF-1 in blood [1].

Traditionally excess secretion of GH has been targeted by treatment strategies to reduce secretion; employing surgery, radiotherapy, dopamine agonists (DOPAs), and/or somatostatin agonists (SSAs) alone or as adjuvant to surgery. Recently Pegvisomant (Somavert ; Pfizer) was developed with the aim of blocking the action of circulating GH. Pegvisomant (PEG) is a genetically engineered analogue of human GH that can compete with endogenous $\mathrm{GH}$ for $\mathrm{GH}$ receptors while failing to activate the receptor. As the effectiveness of PEG depends on competition with $\mathrm{GH}$ the required dose is influenced by endogenous $\mathrm{GH}$ levels which depend on the size, activity and type of adenoma. PEG is administered daily by subcutaneous injection. In Europe, PEG is licensed for patients who have had an inadequate response to surgery and/or radiation and in whom an appropriate medical treatment with somatostatin analogues did not normalise IGF-1 concentrations or was not tolerated[5].

Here we present a systematic review of the evidence about the clinical effectiveness of PEG and an economic analysis to estimate the cost-effectiveness of PEG treatment relative to standard care.

\section{Methods}

The review was conducted according to a predefined protocol (available on request).

\section{Search strategy clinical effectiveness}

The following bibliographic databases and other sources were searched for studies of clinical effectiveness: (i) Bibliographic databases: Cochrane Library (Wiley),
MEDLINE (Ovid), MEDLINE (Ovid) In-Process, EMBASE (Ovid), CINAHL (EBSCO). (ii) Sources of information on ongoing and unpublished research (including the National Research Register and ClinicalTrials). (iii) Sources of Abstracts and Proceedings (ZETOC, ENDO 2006 Endocrine Society's 88 $8^{\text {th }}$ annual meeting). (iv) Citations of relevant studies. (v) Experts in the field were contacted to check that no published or unpublished studies had been missed. (vi) Studies listed in systematic and other reviews. The following bibliographic databases were searched for economic studies: MEDLINE(Ovid); EMBASE (Ovid); Cochrane Library (Wiley); NHS EED, OHE HEED. Electronic databases were searched up to March 2007. No language or date restrictions were applied. Full details are in Additional File 1.

\section{Inclusion and exclusion criteria for clinical studies}

No systematic reviews were identified. Primary studies of effectiveness were selected according the following criteria: Study design: RCTs, quasi-randomised clinical trials, comparative non-randomised studies, or case series if at least 10 patients were included. Population: Patients diagnosed with acromegaly. Intervention: Treatment with PEG. Comparator(s): any other or no treatment. Outcomes: Any clinically relevant outcomes, changes in IGF-1 levels and GH levels. Economic studies were selected using the following criteria: Study design: Cost-effectiveness, cost-utility and cost-benefit studies. Health economic reviews were also included. Population: People with acromegaly. Intervention: PEG. Comparator: Any alternative treatment. Outcomes: Quality of life, costs or incremental costeffectiveness ratio. Conference and symposium abstracts were noted and used to check for studies published as full papers.

The quality of included studies was assessed using standard check lists [6], and appropriate data were extracted from included studies by one reviewer and checked by a second. Application of inclusion criteria, quality assessment and data extraction were undertaken by one reviewer and checked by a second. Disagreements were resolved by consensus.

Heterogeneity of clinical studies precluded meta-analysis and clinical effectiveness was reviewed by narrative synthesis. Studies that were multiply published were checked and the most appropriate trial data extracted. Studies that reported health-related quality of life (QoL) results for patients with acromegaly but did not satisfy the inclusion criteria were noted and if judged relevant were used to inform the economic analysis.

\section{Results}

\section{Number and type of studies identified}

The electronic search yielded 319 citations (see Additional File 2). After removal of duplicates and irrelevant citations 
on the basis of title and/or abstract the full texts of 32 citations were obtained for further scrutiny. On application of inclusion criteria 14 publications were excluded (see Additional File 2 for reasons for exclusion). The main characteristics of the eighteen included publications are summarised in Additional File 3 (further details are provided in Additional File 4). The studies comprised one multicentre RCT (Trainer 2000 [7]) of 112 patients randomised to placebo or three different doses of PEG for 12 weeks; an open label extension of this RCT (Van der Lely 2001 [8]) with additional patients (total $=160$ ) and altered dose regimen; two publications describing analyses of patient subgroups from the RCT $[9,10]$; a retrospective case series $(n=142)$ aimed at monitoring safety of PEG treatment (Biering 2006 [11]); and 13 before versus after PEG treatment comparisons [12-24], one of which [12] was conducted retrospectively. Three of these publications (Paisley 2006; [13] Parkinson 2004 and Parkinson $2003[14,15]$ ) included a comparison with matched healthy subjects in a cross sectional (i.e. single-time measure) design. In several instances the same patients were involved in more than one of the above studies.

\section{Populations recruited}

PEG is licensed for patients with suboptimal response to other treatments or who are intolerant of medical treatment required to normalise GH and IGF-1 levels. The RCT (Trainer 2000 [7]) was conducted prior to licensing. The status of patients relative to the licensed indication is not clear. One study, Colao 2006 [16], did recruit only patients that had not satisfactorily responded to other treatments.

\section{Dose regimens and duration of treatment}

In most studies a large loading dose ( 40 to $80 \mathrm{mg}$ ) of PEG was administered on day one. After the loading dose in the RCT doses of 10,15 or $20 \mathrm{mg} /$ day were given for 12 weeks. In most other studies, after loading, $10 \mathrm{mg} /$ day was administered but adjusted at timed intervals until serum IGF-1 levels had declined to within normal range or a maximum dose (e.g. 30 or $40 \mathrm{mg} /$ day) was reached. The dose regimen was halted, suspended or reduced if serum liver enzymes rose to levels giving clinical concern. Three studies [17-19] employed distinctly different dose regimens from other studies. In Jehle 2005 [17] $(n=10)$, after achieving IGF-1 normalisation, the interval between dosing was first doubled (dose every other day) and then, if IGF-1 normalisation was retained, doubled again. If, after dose-frequency change, IGF-1 reverted to abnormal levels then dose frequency was returned to the previously successful frequency. In Jorgensen 2005 [19] $(n=11)$ PEG was compared to PEG combined with long-acting SSA. In Feenstra 2005 [18] PEG was administered weekly rather than daily but was adjunct to monthly administration of long-acting SSA treatment, and PEG dose was increased until IGF-1 normalisation was achieved.

Follow-up of patients was short term in most studies. Duration of study treatment period varied from as little as 12 weeks in many studies to 12 months in a few, or in the more extended studies up to 2 years for a few patients $[8,9,17,20,21]$ (Additional File 3).

\section{Outcomes reported}

Signs and symptoms of disease were monitored in the RCT and three other studies $[7,16,17,21]$ using patient questionnaires. Serum IGF-1 levels were almost universally reported. GH levels were reported in the RCT and its extension $[7,8]$ and a few small studies $[9,16,19]$. Several studies focussed on risk factors for cardiovascular disease $[13,16,20,22]$, and/or for diabetes $[17,19,20,23]$. Two studies focussed on markers of bone metabolism [10,15]. Side effects and transaminases levels were commonly, but not universally, reported. None of the studies assessed quality of life outcomes.

\section{Risk of bias in included studies}

Withdrawals from treatment in the RCT were fully described and trial arms were balanced at baseline; the publication provided few details of randomisation, allocation concealment or blinding procedures. The greatest risks for bias amongst the remaining studies (Table 1) arose from a lack of clear information about the sampling frame from which study participants had been selected and a lack of description of the selection methods employed. The rarity of acromegaly may have dictated the use of convenience samples in most studies but this was not explicitly reported.

\section{Clinical effectiveness: signs and symptoms of acromegaly}

The RCT [7] elicited patient information on signs and symptoms using a questionnaire rating scale of 0 (no symptoms) to 8 (severe, incapacitating) for each of five symptom categories: soft tissue swelling, headache, joint pain, excessive sweating, fatigue (Figure 1). At 12 weeks statistically significant $(\mathrm{p} \leq 0.05)$ improvements from baseline were noted for the two high dose groups for soft tissue swelling and excessive perspiration, and for all three PEG groups for fatigue. No statistically significant changes occurred for the placebo group except for fatigue which worsened.

The small uncontrolled study of Jehle [17] $(\mathrm{N}=10)$ noted a trend for improvement over a mean treatment period of $15.3( \pm 4.6)$ months. Colao [16] reported a favourable trend toward improvement from baseline for 10 patients; none of the changes in the individual symptom category scores reached statistical significance. Schreiber [21] reported statistically significant improvements (6 months 
Table I: Assessment of risks to bias in non-randomised studies

\begin{tabular}{|c|c|c|c|c|c|c|c|c|c|c|c|}
\hline Study & $\begin{array}{l}\text { Were } \\
\text { eligibility } \\
\text { criteria } \\
\text { explicit? }\end{array}$ & $\begin{array}{c}\text { Was } \\
\text { sample } \\
\text { sourcel } \\
\text { selection } \\
\text { described? }\end{array}$ & $\begin{array}{c}\text { Were } \\
\text { patients } \\
\text { assembled } \\
\text { at same } \\
\text { time? }\end{array}$ & $\begin{array}{c}\text { Was a } \\
\text { method } \\
\text { of } \\
\text { diagnosis } \\
\text { stated? } \ddagger\end{array}$ & $\begin{array}{c}\text { Were } \\
\text { clinical } \\
\text { details } \\
\text { described? }\end{array}$ & $\begin{array}{c}\text { Was } \\
\text { individual } \\
\text { patient } \\
\text { data } \\
\text { reported? }\end{array}$ & $\begin{array}{c}\text { Was } \\
\text { outcome } \\
\text { assessment } \\
\text { blinded? }\end{array}$ & $\begin{array}{l}\text { Was } \\
\text { blinding } \\
\text { method } \\
\text { adequately } \\
\text { described? }\end{array}$ & $\begin{array}{l}\text { Was } \\
\text { follow up } \\
\text { time } \\
\text { stated? } \Phi\end{array}$ & $\begin{array}{c}\text { Were } \\
\text { withdraw } \\
\text { als } \\
\text { stated? }\end{array}$ & $\begin{array}{c}\text { Were } \\
\text { reasons for } \\
\text { withdrawal } \\
\text { stated? }\end{array}$ \\
\hline $\begin{array}{l}\text { Barkan } \\
2005[24]\end{array}$ & $\mathbf{Y}$ & $\mathbf{N}$ & CT & $\mathbf{N}$ & $\mathbf{Y}$ & $\mathbf{N}$ & $\mathbf{N}$ & NA & $\mathbf{Y}$ & $\mathbf{Y}$ & $\mathbf{Y}$ \\
\hline $\begin{array}{l}\text { Jorgensen } \\
\text { 2005[19] }\end{array}$ & $\mathbf{Y}$ & $\mathbf{Y}$ & CT & $\mathbf{N}$ & $\mathbf{Y}$ & $\mathbf{N}$ & $\mathbf{N}$ & NA & $\mathbf{Y}$ & $\mathbf{Y}$ & $\mathbf{Y}$ \\
\hline $\begin{array}{l}\text { Feenstra } \\
2005[18]\end{array}$ & $\mathbf{Y}$ & $\mathbf{N}$ & CT & $\mathbf{N}$ & $\mathbf{Y}$ & $\mathbf{N}$ & $\mathbf{N}$ & NA & $\mathbf{Y}$ & $\mathbf{N}$ & NA \\
\hline $\begin{array}{l}\text { Van der } \\
\text { Lely } \\
200 \text { I [8] }\end{array}$ & $\mathbf{Y}$ & $\mathbf{N}$ & $\mathbf{N}$ & $\mathbf{N}$ & $\mathbf{Y}$ & $\mathbf{N}$ & $\mathbf{N}$ & NA & $\mathbf{Y}$ & $\mathbf{Y}$ & $\mathbf{Y}$ \\
\hline $\begin{array}{l}\text { Sesmilo } \\
2002[9]\end{array}$ & $\mathbf{Y}$ & $\mathbf{N}$ & CT & $\mathbf{Y}$ & $\mathbf{Y}$ & $\mathbf{N}$ & $\mathbf{N}$ & NA & $\mathbf{Y}$ & $\mathbf{Y}$ & $\mathbf{Y}$ \\
\hline $\begin{array}{l}\text { Fairfield } \\
2002[10]\end{array}$ & $\mathbf{N}$ & $\mathbf{N}$ & CT & $\mathbf{N}$ & $\mathbf{Y}$ & $\mathbf{N}$ & $\mathbf{N}$ & NA & $\mathbf{Y}$ & $\mathbf{N}$ & NA \\
\hline $\begin{array}{l}\text { Parkinson } \\
2002[22]\end{array}$ & $\mathbf{N}$ & $\mathbf{N}$ & CT & $\mathbf{N}$ & $\mathbf{Y}$ & $\mathbf{Y} \dagger$ & $\mathbf{N}$ & NA & $\mathbf{N}$ & $\mathbf{N}$ & NA \\
\hline $\begin{array}{l}\text { Parkinson } \\
2003 a[15]\end{array}$ & $\mathbf{Y}$ & $\mathbf{N}$ & CT & $\mathbf{N}$ & $\mathbf{Y}$ & $\mathbf{N}$ & $\mathbf{N}$ & NA & $\mathbf{N}$ & $\mathbf{N}$ & NA \\
\hline $\begin{array}{l}\text { Parkinson } \\
2003 \mathrm{~b}[23]\end{array}$ & $\mathbf{N}$ & $\mathbf{N}$ & CT & $\mathbf{N}$ & $\mathbf{Y}$ & $\mathbf{Y} \dagger$ & $\mathbf{N}$ & NA & $\mathbf{Y}$ & $\mathbf{N}$ & NA \\
\hline $\begin{array}{l}\text { Parkinson } \\
2004[14]\end{array}$ & $\mathbf{N}$ & $\mathbf{N}$ & CT & $\mathbf{N}$ & $\mathbf{N}$ & $\mathbf{Y} \dagger$ & $\mathbf{N}$ & NA & $\mathbf{N}$ & $\mathbf{N}$ & NA \\
\hline $\begin{array}{l}\text { Jehle } \\
2005[17]\end{array}$ & $\mathbf{N}$ & $\mathbf{N}$ & CT & $\mathbf{N}$ & $\mathbf{Y}$ & $\mathbf{Y}$ & $\mathbf{N}$ & NA & $\mathbf{Y}$ & $\mathbf{Y}$ & $\mathbf{Y}$ \\
\hline $\begin{array}{l}\text { Paisley } \\
\text { 2006[13] }\end{array}$ & $\mathbf{N}$ & $\mathbf{N}$ & CT & $\mathbf{N}$ & $\mathbf{Y}$ & $\mathbf{Y}$ & $\mathbf{N}$ & NA & $\mathbf{N}$ & $\mathbf{N}$ & $\mathbf{N}$ \\
\hline $\begin{array}{l}\text { Biering } \\
\text { 2006[I I] }\end{array}$ & CT & $\mathbf{Y}$ & NA & $\mathbf{N}$ & $\mathbf{N}$ & $\mathbf{Y}^{\mathbf{a}}$ & $\mathbf{N}$ & NA & $\mathbf{N}$ & $\mathbf{Y}$ & $\mathbf{Y}$ \\
\hline $\begin{array}{l}\text { Colao } \\
\text { 2006[16] }\end{array}$ & $\mathbf{Y}$ & $\mathbf{Y}$ & $\mathbf{Y}$ & $\mathbf{Y}$ & $\mathbf{Y}$ & $\mathbf{Y}$ & $\mathbf{N}$ & NA & $\mathbf{Y}$ & $\mathbf{Y}$ & $\mathbf{Y}$ \\
\hline $\begin{array}{l}\text { Pivonello } \\
2007[20]\end{array}$ & $\mathbf{Y}$ & $\mathbf{N}$ & CT & $\mathbf{Y}$ & $\mathbf{Y}$ & $\mathbf{Y}$ & $\mathbf{Y}$ & $\mathbf{Y}$ & $\mathbf{Y}$ & $\mathbf{Y}$ & $\mathbf{N}$ \\
\hline $\begin{array}{l}\text { Schreiber } \\
2007[21]\end{array}$ & $\mathbf{N}$ & $\mathbf{Y}$ & $\mathbf{N}$ & $\mathbf{N}$ & $\mathbf{Y}$ & $\mathbf{N}$ & $\mathbf{N}$ & NA & $\mathbf{Y}$ & $\mathbf{Y}$ & $\mathbf{N} \neq \ddagger$ \\
\hline $\begin{array}{l}\text { Parkinson } \\
2007[12]\end{array}$ & $\mathbf{Y}$ & $\mathbf{N}$ & CT & $\mathbf{N}$ & $\mathbf{Y}$ & $\mathbf{Y}$ & $\mathbf{Y}$ & $\mathbf{N}$ & $\mathbf{N}$ & $\mathbf{N}$ & NA \\
\hline
\end{tabular}


vs. baseline score) for soft tissue swelling, headache, joint pain, general physical condition, and for total score. In this study 62 patients (of 229) completed the questionnaire at baseline and 56 at 6 months into treatment. The results may be susceptible to sampling bias. Both the RCT and Jehle study reported statistically significant reductions in finger-ring size that were attributed to PEG therapy.

\section{Clinical effectiveness: tumour volume}

In the RCT PEG treatment did not alter the group mean tumour volumes relative to baseline and no individual patient exhibited a clinically significant increase in tumour volume [7]. In the RCT extension [8] $(\mathrm{N}=131)$ $160 \mathrm{MRI}$ image pairs were collected, one image at baseline and another at an average of 11.5 months into treatment. No statistically significant change from baseline was observed in mean tumour volume. At baseline mean tumour volume was $2.41 \mathrm{ml}$ (95\% CI: 1.8 to 3.0) and after treatment was $2.37 \mathrm{ml}$ (95\% CI: 1.8 to 3.0$)$. The mean of individual change from baseline was - $0.033 \mathrm{ml}$ (95\% CI:
-0.15 to $+0.08 ; \mathrm{p}=0.353$ versus zero change). Two patients had progressive tumour growth requiring treatment, the authors could attribute no cause, and there was no relationship between duration of treatment and change in tumour size. Colao [16] reported a baseline mean tumour size of $1.23 \mathrm{ml}$ (95\% CI: 0.55 to 1.91 ) for 14 patients; after treatment mean volume was $1.20 \mathrm{ml}$ (95\% CI; 0.46 to 1.95); the mean change in volume was $0.026 \mathrm{ml}(95 \% \mathrm{CI} ;-0.21$ to +1.56$)$. Jehle [17] observed small clinically insignificant increases in tumour size in 2 of 10 patients (duration of treatment 12 to 20 weeks). Dual-therapy (PEG + SSA) studies $[18,19]$ reported similar results (statistically non-significant).

\section{Clinical effectiveness: achievement of normal IGF-I levels} In the RCT [7] IGF-1 normalisation was the primary outcome. Baseline IGF-1 levels were at least 1.3 times above the top of the normal range. Statistically significant reductions in IGF-1 occurred after treatment in all three PEG groups but not the placebo group (Figure 2); at all time intervals after baseline statistically significant differences

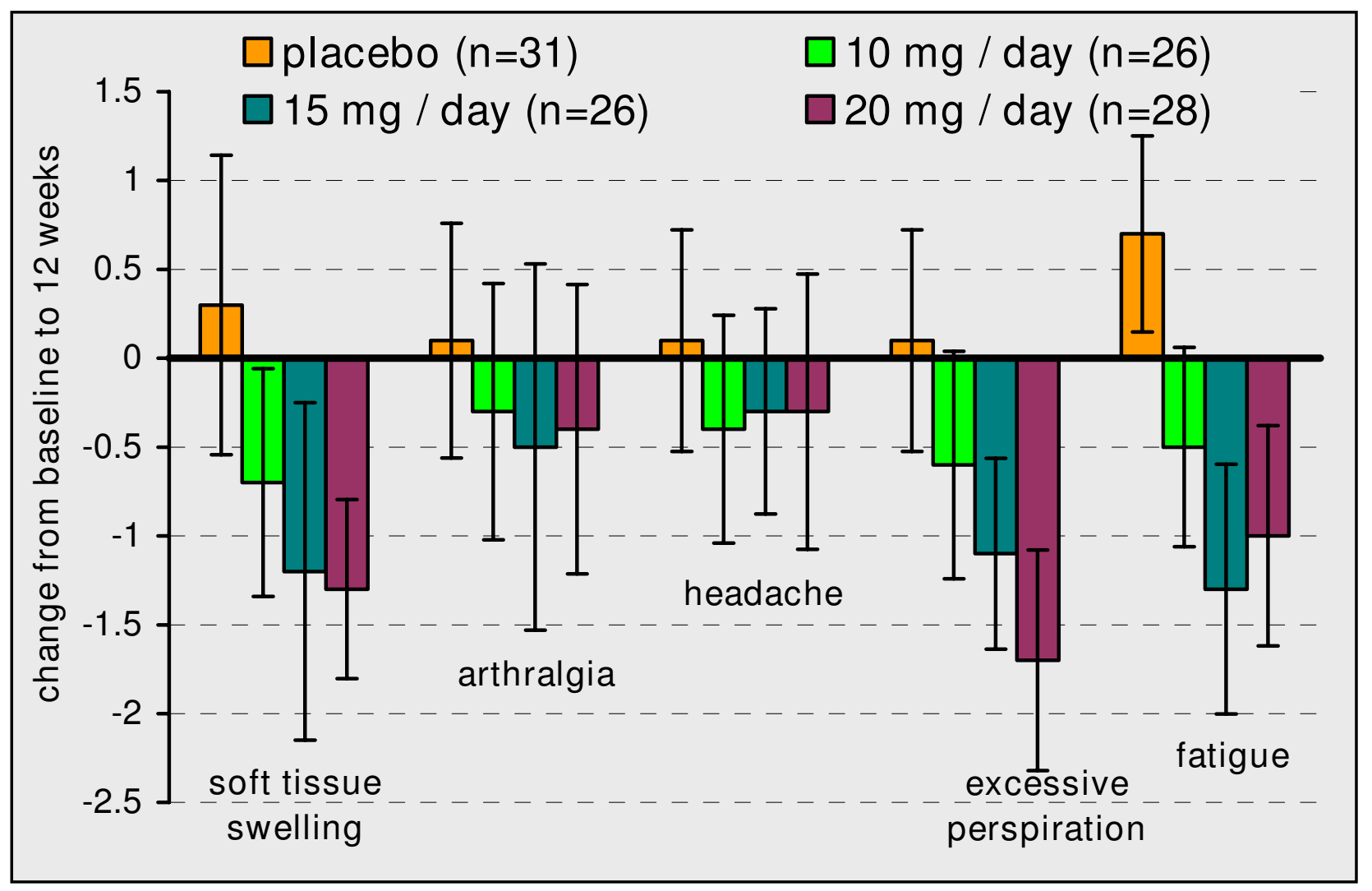

Figure I

Change in signs and symptoms of acromegaly reported in the $\mathbf{R C T}$. Mean and $95 \%$ confidence intervals of change at 12 weeks relative to baseline. Raw data taken from Trainer 2000 [7]. 
were observed for each PEG regimen versus placebo. A distinct dose response relationship was evident with higher doses more effective than $10 \mathrm{mg}$ PEG/day. At 12 weeks the proportion of patients with normalised IGF-1 levels was $10 \%, 38 \%, 75 \%$ and $82 \%$ in placebo, $10 \mathrm{mg}, 15 \mathrm{mg}$, and 20 mg PEG groups respectively. In the RCT extension [8] PEG dose was titrated to achieve normal range IGF-1 with a maximum allowed dose of $40 \mathrm{mg} /$ day. Figure 2 shows the reported IGF-1 levels. In the cohort treated for 12 months $(\mathrm{n}=90) 97 \%$ had normalised IGF-1 levels.

Schreiber [21] collected IGF-1 data for 157 of 229 patients at baseline and for 147, 102, and 39 patients after 6, 12 and 24 months (Figure 2). Mean group values were similar to those in the RCT extension [8]. At baseline 11\% had normal range IGF-1 and at 6,12 and 24 months of treatment $64 \%, 71 \%$, and $76 \%$ were in normal range. These percentages are distinctly lower than the $97 \%$ reported in the RCT extension. Schreiber et al suggested this may be due to better patient compliance and superior monitoring for dose adjustment in a clinical trial compared to the real world clinical practice reflected in their study. Colao [16] reported individual IGF-1 levels for 16 patients that fitted the licensed indication for PEG. Of 14 patients evaluated at 12 months eight (57\%) reduced IGF-1 to within normal range and three more to within 1 to 1.3 times normal range.

Feenstra 2005 [18] and Jorgensen 2005 [19] combined PEG with SSA therapy, whilst Jehle 2005 [17] attempted reduction of dose frequency (Figure 2). Because daily PEG is very expensive these strategies might reduce the overall cost of maintaining IGF-1 within normal range. In Feenstra [18] at 18 weeks IGF-1 was normalised in 21/26
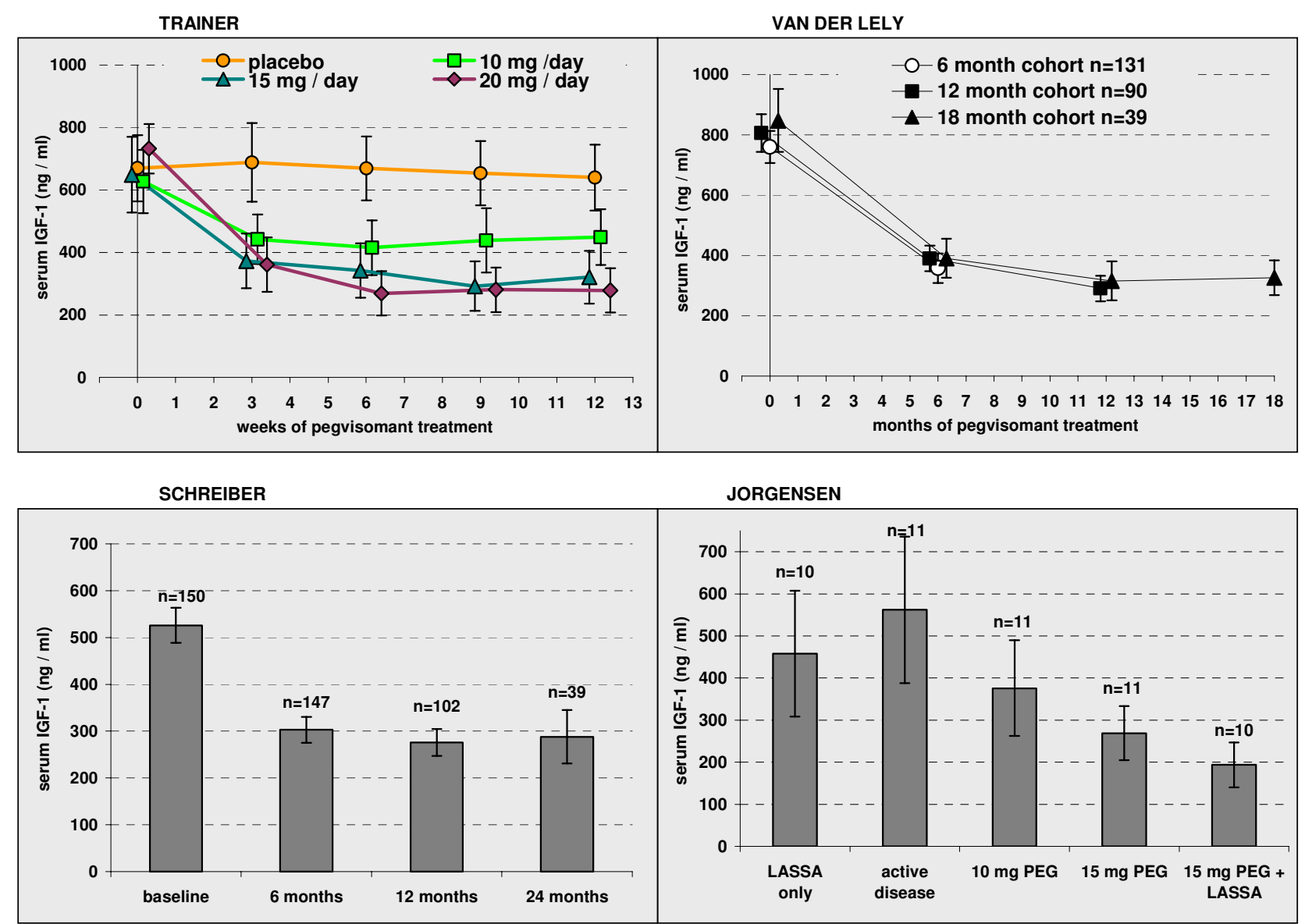

\section{Figure 2}

Decline in IGF-I levels with PEG treatment. Baseline and follow up mean values with $95 \%$ confidence intervals reported in randomised [7] and non-randomised studies. The duration of treatment in the 5 phases of the Jorgensen study [19] was 2 to 4 weeks, 8 weeks, 6 weeks, 6 weeks and I 2 weeks. Dose of PEG in the RCT extension [8] and in Schreiber [2I] varied according to patient response. Figure compiled from published data $[7,8,19,21]$ with the addition of $95 \% \mathrm{Cl}$. 
(81\%) patients, and at 42 weeks in 95\% (18/19 evaluated); the median weekly PEG dose to achieve normalisation in those normalised was $60 \mathrm{mg} /$ week. The Jorgensen study [19] comprised 5 study phases: therapy with SSA, withdrawal from SSA for 2 months, PEG at $10 \mathrm{mg} /$ day ( 6 weeks), PEG at $15 \mathrm{mg} /$ day (6 weeks), and finally 12 weeks of $15 \mathrm{mg}$ /day PEG combined with $30 \mathrm{mg}$ long acting SSA every 2 to 4 weeks. IGF-1 was measured at the end of each study phase. The final combined therapy reduced IGF-1 to lower levels than single therapy with either LASSA or PEG but the difference just failed to reach statistical significance. The lack of a true control for each phase of study and problems of treatment carryover complicate interpretation of these results. On combined therapy 9 of 10 patients achieved normal IGF-1 levels. Jehle 2005 [17] investigated 10 patients who had failed to normalise IGF1 with DOPAs or SSAs. Mean PEG treatment was for 15.3 months; all patients normalised IGF- 1 and 5 were able to reduce frequency of dose administration to less than daily while retaining a normal IGF-1.

\section{Clinical effectiveness: effect on $\mathrm{GH}$ levels}

In the RCT PEG treatment substantially increased serum GH levels by up to $15 \mathrm{ng} / \mathrm{ml}$ above baseline levels (of 8 $\mathrm{ng} / \mathrm{ml}$ ) and the increase from baseline reached statistical significance for all three dose regimens. However, for patients receiving placebo the change was small and not statistically significant (Figure 3). A dose response relationship was evident with higher dose inducing greater increase. In the RCT extension [8] for the cohort treated for 6 months with PEG the mean GH level was substantially elevated to double that at baseline (Figure 3).

Colao [16] reported individual GH levels for 16 patients. The mean baseline GH ranged from 3.4 to $74.8 \mathrm{ng} / \mathrm{ml}$ (mean 23ng/ml; 95\% CI: 10.9 to 35.0 ). After treatment, discounting one patient who failed to inject PEG, the range was 6.3 to $145 \mathrm{ng} / \mathrm{ml}$ (mean $33.1 ; 95 \% \mathrm{CI}: 11.3$ to 54.9). Not all patients increased their GH level. The range of change from baseline was -17 to $+52 \mathrm{ng} / \mathrm{ml}$ and group mean change from baseline was $+10.8 \mathrm{ng} / \mathrm{ml}$ (95\% CI -1.7 to +23.3$)$.

In the study of Jorgensen 2005 [19] $(n=11)$ PEG treatment alone more than doubled group mean GH levels. Subsequent combination of $15 \mathrm{mg}$ PEG/day with LASSA treatment (every two to four weeks) appeared to decrease $\mathrm{GH}$ levels and suppress some of the induced rise due to PEG (difference in group means not statistically significant). PEG may interfere with commercial kit-based immunoassays for GH Paisley et al 2007 [25], and this could impact on the quantitative interpretation of published results.
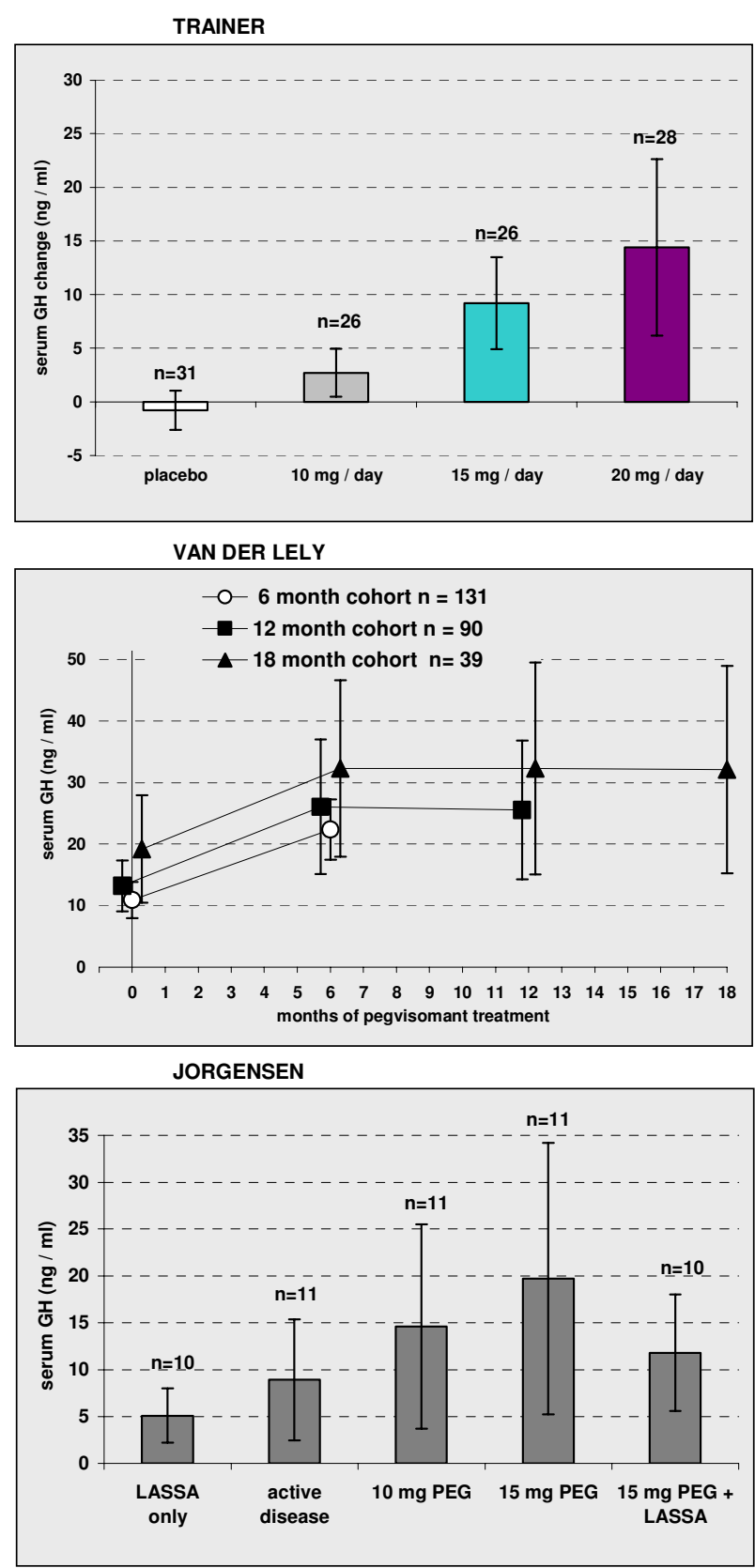

\section{Figure 3}

Increase in GH levels with PEG treatment. Baseline and follow up mean values with $95 \%$ confidence intervals reported in randomised [7] and non-randomised studies. The duration of treatment in the 5 phases of the Jorgensen study [19] was 2 to 4 weeks, 8 weeks, 6 weeks, 6 weeks and 12 weeks. Dose of PEG in the RCT extension [8] varied according to patient response. Figure compiled from published data $[7,8,19]$ with the addition of $95 \% \mathrm{Cl}$. 


\section{Clinical effectiveness: adverse events and withdrawal from} treatment

In the RCT [7] the 20mg/day PEG group experienced slightly higher rates of adverse events than the placebo group (Table 2). One patient withdrew from PEG because of persistent headache and another due to raised serum level of liver enzyme; one placebo patient also withdrew for persistent headache. The RCT extension [8], and studies of Schreiber [21], and Jehle [17] also reported adverse events (Table 2). The RCT extension [8] reported higher rates of adverse events than the RCT. Of 160 participants who received PEG thirty (19\%) withdrew from treatment for various reasons (nine for adverse events, five for lack of efficacy, twelve "voluntarily", and two each were lost to follow up or "violated protocol"). Overall withdrawal in Schreiber [21] was unclear. In the 12 month study of Colao [16] four of 16 patients (25\%) withdrew or were withdrawn, one each for: failure to inject PEG; raised liver enzyme level; inability to follow the protocol; poor compliance. The RCT extension [8] reported that liver enzyme activities in serum remained within normal range during PEG treatment. Schreiber [21] reported abnormally raised serum levels of liver enzymes in 21 of 229 (9\%) patients; in 12 of these the levels were $\geq 3$-fold above normal. Of

Table 2: Rate of adverse events reported in RCT and non-randomised studies

\begin{tabular}{|c|c|c|c|c|c|c|c|}
\hline Adverse event & $\begin{array}{c}\text { Trainer } \\
\text { 2000[7] } \\
\text { Placebo } \\
\mathbf{n}=\mathbf{3 2}\end{array}$ & $\begin{array}{c}\text { Trainer } \\
2000[7] \\
\text { PEG } 10 \mathrm{mg} / \mathrm{d} \\
\mathrm{n}=\mathbf{2 6}\end{array}$ & $\begin{array}{c}\text { Trainer } \\
\text { 2000[7] } \\
\text { PEG I5 } \mathbf{m g / d} \\
\mathbf{n}=\mathbf{2 6}\end{array}$ & $\begin{array}{c}\text { Trainer } \\
\text { 2000[7] } \\
\text { PEG 20mg/d } \\
\text { n }=\mathbf{2 8}\end{array}$ & $\begin{array}{c}\text { I†Open label } \\
\text { van der Lely } \\
(2001)[8] \\
\text { PEG } \\
n=160\end{array}$ & $\begin{array}{c}\text { Tा ††Open } \\
\text { label Scheiber } \\
\text { (2007)[2I] } \\
\text { PEG } \\
\text { n = 229 }\end{array}$ & $\begin{array}{c}\text { t†'Open label } \\
\text { Jehle } \\
\text { (2005)[17] } \\
\text { PEG } \\
n=10\end{array}$ \\
\hline Infections & $5 *(16 \%)$ & $5 *(19 \%)$ & $4 *(15 \%)$ & $5 *(18 \%)$ & $52(33 \%)$ & & I (10\%) \\
\hline Headache & $4(12 \%)$ & $3(12 \%)$ & $2(8 \%)$ & $3(11 \%)$ & 41 (26\%) & $4(1.7 \%)$ & $3(30 \%)$ \\
\hline $\begin{array}{l}\text { Injection-site } \\
\text { reaction }\end{array}$ & $0(0 \%)$ & $2(8 \%)$ & I (4\%) & $3(11 \%)$ & $18(11 \%)$ & 17 (7.4\%) & -- \\
\hline Pain & $2(6 \%)$ & $2(8 \%)$ & I (4\%) & $4(14 \%)$ & $36(23 \%)$ & -- & -- \\
\hline Diarrhoea & I (3\%) & I (4\%) & $0(0 \%)$ & $4(14 \%)$ & $23(14 \%)$ & -- & -- \\
\hline Nausea & I (3\%) & $0(0 \%)$ & $2(8 \%)$ & $4(14 \%)$ & -- & -- & -- \\
\hline Flatulence & $0(0 \%)$ & $0(0 \%)$ & I (4\%) & $3(11 \%)$ & -- & -- & $-v$ \\
\hline $\begin{array}{l}\text { Influenza-like } \\
\text { syndrome }\end{array}$ & -- & -- & -- & -- & $33(21 \%)$ & -- & -- \\
\hline Accidental injury & -- & -- & -- & -- & $28(18 \%)$ & -- & -- \\
\hline $\begin{array}{l}\text { Hypercholesterol } \\
\text { emia }\end{array}$ & -- & -- & -- & -- & 23 (14\%) & -- & -- \\
\hline Back pain & -- & -- & -- & -- & $21(13 \%)$ & -- & -- \\
\hline Asthenia & -- & -- & -- & -- & 21 (13\%) & -- & -- \\
\hline Arthralgia & -- & -- & -- & -- & $19(12 \%)$ & -- & -- \\
\hline Sinusitis & -- & -- & -- & -- & $16(10 \%)$ & -- & -- \\
\hline $\begin{array}{l}\text { Insomnia } \\
\text { (transient) }\end{array}$ & -- & -- & -- & -- & -- & -- & $2(20 \%)$ \\
\hline Fatigue & -- & -- & -- & -- & -- & -- & $3(30 \%)$ \\
\hline
\end{tabular}

ПNumber of patients (\%) with adverse events that occurred in at least $10 \%$ of patients.

IP Number of patients (\%) with adverse events occurring in $>1 \%$ and judged potentially causally related to PEG treatment.

† mean follow up 61 weeks. t† maximum follow up 102 weeks. †t† follow up 10 to 20 months. * upper respiratory tract infection only. 
the 12 with very elevated levels seven patients returned to normal during PEG treatment, levels returned to normal in four patients after withdrawal of PEG and in one patient level remained high but PEG was continued. Details of six of Schreiber's patients were reported by Biering 2006 [11]. In this report 6 of 142 (4\%) withdrew permanently from PEG because of raised liver enzyme levels.

\section{Clinical effectiveness: miscellaneous outcome measures} A miscellany of further outcomes were reported mostly from retrospective laboratory analyses of serum samples for surrogate markers of disease-risk (diabetes, cardiovascular disease, maladjusted bone turnover) in subgroups of patients from other studies (mainly the RCT [7] and/or its extension [8]). Four studies $[9,13,16,22]$ reported on statistical significance of before versus after PEG treatment changes in the levels of several risk markers for cardiovascular disease. The findings (Table 3) were not consistent between studies and no firm conclusions justifiable. One study reported statistically significant improvement in cardiac structure and function after 18 months of PEG treatment using Doppler echocardiography[20].

Two studies $[10,15]$ presented data on serum markers of bone metabolism. The results (Table 4) support the proposition that PEG reduces bone turnover in acromegaly; how this translates to patient benefit requires further investigation. Several small non-randomised studies reported on laboratory measures relating to insulin and/ or glucose metabolism; these included those of Barkan $2005(\mathrm{n}=53)$ [24], Parkinson $2002(\mathrm{n}=20)$ [22], Parkinson 2003b $(\mathrm{n}=16)$ [23], Colao $2006(\mathrm{n}=16)$ [16], Jehle $2005(n=10)$ [17], Jorgensen $2005(n=11)$ [19]. The general direction of findings was for a favourable change indicative of improved metabolic adjustment. The significance of these findings for patient well-being is difficult to judge.

\section{Economic analysis}

One publication was included. This 2005 Technology Assessment [26] for the Welsh Medicines Partnership (WMP) described and critiqued a manufacturer's (Pfizer UK Ltd) submitted decision analytic model of PEG treatment versus standard care (SC) from the perspective of the UK NHS. The WMP re-ran the model using "preferred parameters". We were provided with a working version of the manufacturer's model (MM). Figure 4 shows the decision tree structure of the model.

\section{Description of Manufacturer's Model}

The MM assumed SC to be treatment with long acting SSAs. It considered 100,000 English male patients starting treatment at an average age of 45 years and continuing PEG for at least 20 years. Benefits of PEG derived from improved survival and improved quality of life (QoL).
The survival of SC patients (the comparator population) was obtained by applying a standardised mortality ratio for acromegaly (2.63, Bates 1993 [27]) to the National Statistics life table for English men aged 45 to 65 years. To calculate survival benefit it was assumed that $92 \%$ of PEG treated patients were responders and attained the survival probability of English males while 8\% were non-responders and remained in PEG treatment with the survival probability of standard care (SC) patients. For those who stopped PEG treatment after 20 years survival probability at each subsequent year thereafter was the same as that for the SC survivors to that year. The resulting survival curves are shown in Figure 4. The survival benefit was calculated from the difference between survival curves. In the absence of pertinent data a utility gain in QoL was assumed to be equal to the disutility of patients experiencing a coronary event $(0.83-0.75=0.08)$ and in the $\mathrm{MM}$ was experienced by all PEG treated patients (including the $8 \%$ non-responsive PEG-treated patients). The same gain was applied for each year of PEG treatment. With discounting at $3.5 \%$ for costs and benefits the MM delivered incremental cost-effectiveness ratios (ICERs) at 20 years of $£ 105 \mathrm{~K} /$ quality adjusted life year (QALY) and $£ 194 \mathrm{~K} /$ life year gained (LYG).

\section{Welsh Medicines Partnership's re-run of Manufacturer's Model}

The WMP re-ran the MM using preferred parameters that included survival of PEG responders taken as that of a mix of Welsh men and women in proportion and with survival probability from National Statistics life tables; survival in SC was obtained by applying an SMR of 1.55 (Orme 1998 [28]). The impact of these changes on the difference in survival curves for PEG and SC treated individuals is shown in Figure 4 . The ICER generated at 20 years was $£ 748 \mathrm{~K} / \mathrm{LYG}$.

\section{Current author's re-run of Manufacturer's Model}

We estimated a feasible lower limit for the ICER of PEG treatment versus SC. To do this we adopted a "perfect drug" scenario in which model inputs were all in favour of PEG relative to SC but remained within reasonable bounds set by available information. We assumed complete compliance with PEG treatment and complete effectiveness so that survival and QoL were returned to those of the general population. This simplifies the model by eliminating the non-responder arm (dashed line in Figure 4 ) as it was unrealistic that non-responder patients would persist with PEG for 20 years. With regard to survival we adopted two further changes: first the general population was taken from National Statistics life tables for English men and women aged 45 onwards; second we applied a standardised mortality ratio of 3.6. We reasoned that survival of acromegaly patients eligible for PEG would likely be poorer than for the generality of acromegaly patients, 
Table 3: Risk indicators for CVD: comparison for before v. after PEG There were small numbers of participants and changes for most markers did not reach statistical significance

\begin{tabular}{|c|c|c|c|c|c|}
\hline & $\begin{array}{c}\text { Sesmilo } 2002[9] \S \\
n=26\end{array}$ & $\begin{array}{c}\text { Colao } 2006[16] \\
n=16\end{array}$ & $\begin{array}{c}\text { Parkinson } 2002[22] \dagger \\
n=20\end{array}$ & $\begin{array}{c}\text { Parkinson } 2002[22] \dagger \\
n=20\end{array}$ & $\begin{array}{c}\text { Paisley } 2006[13]^{*} \\
n=20\end{array}$ \\
\hline PARAMETER & $\begin{array}{c}\text { Mean change from base- } \\
\text { line } P\end{array}$ & $\begin{array}{l}\text { Paired } t \text { test } \\
\text { Before } \\
v . \\
\text { after Tx } P\end{array}$ & $\begin{array}{c}\text { Paired t test Before } \\
\text { v. } \\
\text { after Tx } P\end{array}$ & $\begin{array}{c}\text { Cases: } \\
\text { Before Tx } \\
\text { v. } \\
\text { after Tx P }\end{array}$ & $\begin{array}{c}\text { Cases before Tx } \\
\text { v. } \\
\text { Healthy controls } P\end{array}$ \\
\hline Total chol (mM) & $0.22 \mathrm{NS}$ & NS & Increased $<0.01$ & Increased $<0.01$ & 0.16 \\
\hline HDL chol (mM) & $0.006 \mathrm{NS}$ & Increased $\mathbf{0 . 0 0 1 7}$ & NS & -- & -- \\
\hline LDL chol (mM) & $-0.13 N S$ & -- & Increased $<0.01$ & -- & -- \\
\hline$[$ Total/HDL] chol & $0.21 \mathrm{NS}$ & Reduced $\mathbf{0 . 0 0 1 2}$ & -- & -- & -- \\
\hline TG (mM) & 0.250 .007 & NS & NS & 0.3 & 0.13 \\
\hline Lipo (a) (mg/l) & -700.039 & -- & Reduced $<0.01$ & -- & -- \\
\hline Apo B & -- & -- & Increased $<0.01$ & -- & -- \\
\hline Apo Al & -- & -- & Increased $<0.05$ & -- & -- \\
\hline Homocysteine (?M) & $-0.16 N S$ & -- & -- & -- & -- \\
\hline CRP & 20.0002 & -- & -- & -- & -- \\
\hline Interleucin 6 & $0.17 \mathrm{NS}$ & -- & -- & -- & -- \\
\hline Blood pressure & -- & NS & -- & -- & -- \\
\hline Fibrinogen & -- & NS & -- & -- & -- \\
\hline Heart rate & -- & NS & -- & -- & -- \\
\hline MMP-2 (ng/ml) & -- & -- & -- & Reduced $<0.001$ & Higher $<0.001$ \\
\hline MMP-9 & -- & -- & -- & 0.76 & 0.87 \\
\hline VEGF & -- & -- & -- & Reduced $\mathbf{0 . 0 0 8}$ & 0.18 \\
\hline
\end{tabular}

$\S$ results for the open label part of the study, patients included if they normalised IGF-I with treatment. It is unclear if the number of patients analysed was 34 or 26 . † Units for Total chol and total TG given in paper as $\mathrm{mM}$ but are actually $\mathrm{mg} / \mathrm{dl}$. * It is possible that some participants may have been used in both these studies.

Apo $\mathrm{AI}=$ apoprotein $\mathrm{AI}$ (on HDL \& chylomicrons). $\mathrm{Apo} B=$ apoprotein $\mathrm{B}$ (on LDL). chol = cholesterol $\mathrm{CRP}=\mathrm{C}$-reactive protein. $\mathrm{HDL}=$ high density lipoprotein. $\mathrm{LDL}=$ low density lipoprotein. Lipo $(a)=$ lipoprotein little a. MMP = matrix metalloproteinase. NS = not statistically significant. $P=$ probability. $P E G=$ pegvisomant. $T G=$ triacyl glyceride. $T x=$ treatment. VEGF $=$ vascular endothelial growth factor.

Note: There were small numbers of participants and changes for most markers did not reach statistical significance.

such as those in Orme [28]. Thus, we assumed survival of patients eligible for PEG to be more like that observed in early studies before the development of long acting SSAs which normalise IGF-1 and GH in many patients. In addition many of the patients eligible for PEG will have had radiotherapy which is a known independent indicator of poorer survival $[29,30]$. We therefore examined standard- ised mortality ratios from studies of more than a decade ago (Figure 5). We increased the highest ratio from these studies by $10 \%$ giving a standardised mortality ratio for the perfect drug scenario of 3.6. The resulting survival curves are compared with the MM and WMP curves in Figure 4. 
Table 4: Indicators of bone formation and soft tissue turnover

\begin{tabular}{|c|c|c|c|c|c|c|}
\hline MARKER & $\begin{array}{l}\text { Parkinson } 2003 \\
{[15] \Phi \text { baseline }}\end{array}$ & 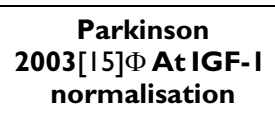 & P v. baseline & $\begin{array}{c}\text { Fairfield } \\
\mathbf{2 0 0 2}[10] \Phi \Phi \\
\text { placebo I } \mathbf{2} \text { wks }\end{array}$ & $\begin{array}{c}\text { Fairfield } \\
\text { 2002[10]ФФPEG } \\
\text { I } 2 \text { wks }\end{array}$ & P v. placebo \\
\hline \multicolumn{7}{|l|}{ Bone formation } \\
\hline osteocalcin & $47^{\theta}(14-109)$ & $21(10-73)$ & $<0.001$ & $+0.01^{\theta \theta}(0.39)$ & $-2.2(0.44)$ & 0.009 \\
\hline $\begin{array}{l}\text { terminal propeptide } \\
\text { procollagen I }\end{array}$ & $70^{\theta}(12)$ & $38(8)$ & $<0.01$ & $+18.1^{\theta}(12.8)$ & $-23.6(9.6)$ & 0.022 \\
\hline $\begin{array}{l}\text { bone alkaline } \\
\text { phosphatase }\end{array}$ & $147^{\theta \theta \theta}(29)$ & $120(23)$ & $<0.05$ & & & \\
\hline \multicolumn{7}{|l|}{ Bone resorption } \\
\hline $\begin{array}{l}\text { cross linked } \\
\text { telopeptide of } \\
\text { collagen I }\end{array}$ & $0.8^{\Psi}(0.2-2.4)$ & $0.4(.03-1.3)$ & $<0.0001$ & $+I^{\theta \theta}(0.3)$ & $-4.4(1.4)$ & 0.024 \\
\hline $\begin{array}{l}\text { urinary ratio cross } \\
\text { linked telopeptide/ } \\
\text { creatinine }\end{array}$ & $92^{\theta \theta \theta}$ & $56(14)$ & $<0.01$ & & & \\
\hline \multicolumn{7}{|l|}{$\begin{array}{l}\text { Soft tissue } \\
\text { formation }\end{array}$} \\
\hline $\begin{array}{l}\text { terminal propeptide } \\
\text { of procollagen III }\end{array}$ & $4.3^{\theta}(0.3)$ & $3.1(0.3)$ & $<0.01$ & & & \\
\hline
\end{tabular}

$\Phi$ data are mean (SEM) or median (range); $\Phi \Phi$ data are mean (SEM); $\theta$ ug/L; $\theta \theta$ nmol/L; $\theta \theta \theta$ units unclear. $\Psi$ pmol/L.

Several studies [31-36] have now reported poorer QoL for acromegaly patients relative to the general population; the direction of evidence from these points to a negative relationship between QoL and IGF-1 levels, but no studies have examined utility gain from PEG treatment. Rowles 2005 [31] reported utility values for QoL of acromegaly patients $(72.5 \%$ had active disease, $27.5 \%$ were in remission). Median utility was 0.7 (range -0.07 to 0.92 ) compared to 0.81 for matched members of the general public. To allow for the fact that patients eligible for PEG would correspond to patients with active disease we approximated the utility of such patients as 0.66 (i.e. 0.81 $([0.81-0.7] \times[1 / 0.725]))$. The utility gain in the perfect drug scenario was therefore 0.15 (i.e. 0.81 - 0.66) compared to 0.08 in the MM.

The average dose of PEG/day for UK patients is $16.5 \mathrm{mg}$ (Pfizer UK Ltd, personal communication). At $£ 100 / 20 \mathrm{mg}$ (BNF [37]) the average acquisition cost for PEG was taken as $£ 30,133 \mathrm{pa}$ (assuming vial splitting as necessary). Additional cost for MRI scans and laboratory tests (IGF-1 and serum levels of liver enzymes) were £349pa (expert clinical opinion and NHS reference costs [38]). For the perfect drug scenario we assumed standard care patients were all treated with long acting SSAs; this assumption favours
PEG since some patients are resistant to LASSAs and if given pharmacotherapy would receive much cheaper drugs (e.g. DOPAs). The MM used an annual acquisition cost for long acting SSAs of $£ 13,289$; other independent estimates range from $£ 9,000$ to $£ 12,000$ [39] and $£ 7,000$ to $£ 14,000$ [40]. We used $£ 13,289 \mathrm{pa}$. In addition, SC included costs for scans and laboratory tests (£349pa as above) and $£ 1,771 \mathrm{pa}$ for treatments of co-morbidities (Didoni 2004 [41]). The total annual cost for PEG and for SC was $£ 30,482$ and $£ 15,409$ respectively.

At 20 and 40 years, with the inputs described above, the perfect drug scenario delivers ICERs of $£ 81 \mathrm{~K} / \mathrm{QALY}$ and $£ 212 /$ LYG and $£ 65 \mathrm{~K} / \mathrm{QALY}$ and $£ 94 \mathrm{~K} / \mathrm{LYG}$ respectively. To reduce the ICER at 20 years to $£ 30 \mathrm{~K} / \mathrm{QALY}$ would require a reduction in PEG cost by about one third.

\section{Discussion}

With regard to the volume and quality of evidence on the effectiveness of PEG, difficulties in patient recruitment may partly explain the existence of only a single RCT, and the participation of overlapping populations of patients amongst multiple studies. Most non-randomised evidence came from "convenience" samples and these studies were susceptible to biases of patient selection and in 

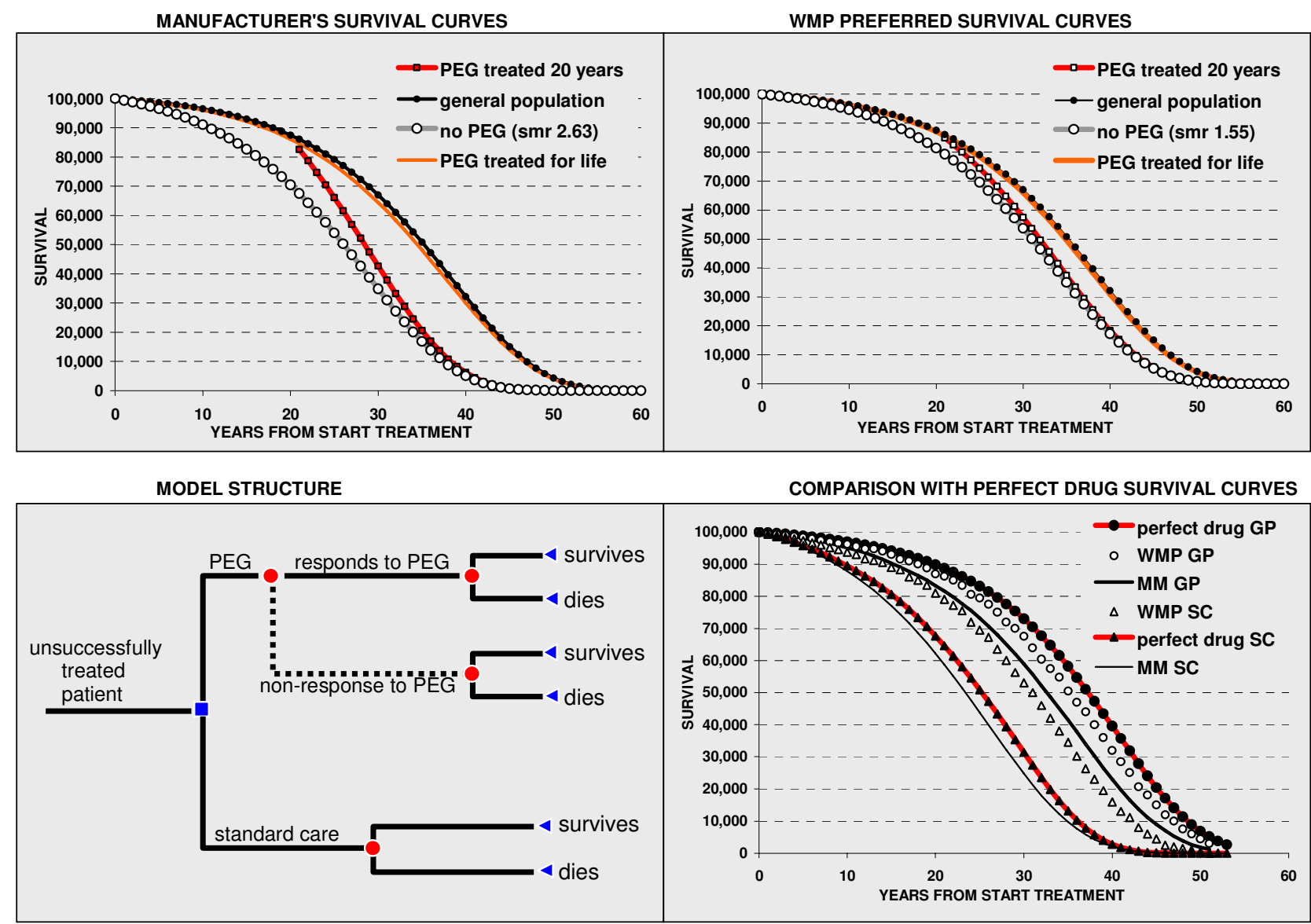

\section{Figure 4}

Model structure and survival curves. Manufacturer's (MM), Welsh Medicines Partnership (WMP) and perfect drug scenario (PD) input survival curves used in economic model. Data input shown as symbols, solid lines represent Gompertz distributions fit to data. In the MM and WMP models PEG treatment continues for 20 years and compliance is $92 \%$. GP $=$ general population (survival in PEG-compliant patients returns survival to that of the general population). SC = standard care (survival in standard care derived by applying a standardised mortality rate (SMR $=2.63$ for MM, I.5 for WMP, and 3.6 for PD) to the survival of the GP). The curves shown are modelled using mortality data from the Office of National Statistics for England (population about 50 million) or for Wales (population about 5 million) as appropriate.

some cases incomplete follow up. In general, study size was small and follow up was short with relatively little or unclear reporting about withdrawals from treatment. It is likely very few studies investigated the "licensed population". The RCT was conducted before licensing. In 2006 Colao [16] commented "all these studies were not designed to investigate the response to pegvisomant in patients with proven resistance to long-term, high dose therapy with somatostatin analogues; these are the patients allowed to receive pegvisomant treatment in Europe according to the product label."

Convincing evidence indicated that adequate dosage of PEG delivers significant reductions in IGF-1 levels and a substantial proportion of such patients are brought within normal range $[7,8,16,18,21]$. In contrast the levels of $\mathrm{GH}$ appear on average to be considerably increased by PEG treatment as shown in the twelve week RCT [7], the uncontrolled extension [8] and by two small non-randomised studies $[16,19]$. Individual patient data shows GH may not increase in all patients [16]. Tumour size is apparently unaffected by PEG treatment $[8,16-19,21,24]$, at least in the short term, however continued vigilant monitoring of tumour size is mandatory during PEG treatment.

In the twelve week RCT [7] PEG improved patient scores for five signs and symptoms of disease (soft tissue swelling, arthralgia, headache, excessive perspiration and fatigue). The improvements reached statistical significance for tissue swelling, perspiration and fatigue. Several 


\begin{tabular}{|c|c|}
\hline $\begin{array}{l}\text { older than } 10 \text { years } \\
\text { Wright } 1970 \\
\text { Alexander } 1980 \\
\text { Nabarro } 1987 \\
\text { Bengsston } 1988 \\
\text { Rajasoorya } 1994 \\
\text { Extabe } 1993 \\
\text { Bates } 1993 \\
\text { last } 10 \text { years } \\
\text { Orme } 1998 \\
\text { Swearingen } 1998 \\
\text { Abosch } 1998 \\
\text { Shimatsu } 1998 \\
\text { Beauregard } 2003 \\
\text { Arita } 2003 \\
\text { Biermasz } 2004 \\
\text { Holdaway } 2004 \\
\text { Ayuk } 2004 \\
\text { K'-Makelin } 2005 \\
\text { Trep } 2005\end{array}$ & $\begin{array}{l}\text { SMR }(95 \% \mathrm{CI}) \\
1.80(1.32,2.28) \\
3.30(2.34,4.26) \\
1.30(0.93,1.67) \\
3.20(2.40,4.00) \\
3.00(1.96,4.04) \\
3.20(1.22,5.18) \\
2.63(1.66,3.60) \\
\\
\\
1.60(1.44,1.76) \\
1.16(0.50,1.82) \\
1.28(0.81,1.75) \\
2.10(1.65,2.55) \\
2.14(1.15,3.13) \\
1.17(0.48,1.86) \\
1.33(0.84,1.82) \\
1.22(0.94,1.50) \\
1.26(1.01,1.51) \\
1.16(0.86,1.46) \\
1.34(0.61,2.07)\end{array}$ \\
\hline & \\
\hline
\end{tabular}

Figure 5

SMR values reported in acromegaly studies. Standardised mortality ratios reported in studies of patients with acromegaly, sorted according publication in last decade or earlier.

small non-randomised studies reported similar trends in improvement.

Increased mortality in acromegaly has been associated with cardiovascular problems. The effect of PEG upon risk indicators for cardiovascular disease was examined in several of the non-randomised studies included in this review but the results were not wholly consistent or easily interpreted. A single small 18 month non-randomised study [20] provided evidence that PEG induces favourable changes in cardiac structure and performance.

The limited available information indicates that PEG has a generally mild adverse event profile but occasionally raises liver enzyme levels necessitating temporary or very occasionally permanent withdrawal $[16,21]$. This means monitoring for possible liver damage is a necessity during long term administration of PEG. Other side effects include headache, injection-site reactions, flu-like syndrome and recently injection-site lipodystrophy sufficient to cause discontinuation has been reported [42]. Antibodies to PEG appear rarely to have been measured. Evidence is lacking about any relationship between anti-GH anti- bodies and decrease in efficacy or an increase in adverse events frequency.

The economic model with input parameters all favouring PEG relative to standard care (a perfect drug scenario) showed that over a 20 year time horizon the cost effectiveness of PEG is very unlikely to fall below $£ 80,000 / \mathrm{QALY}$ or $£ 212,000 /$ LYG. In the absence of special criteria for the assessment of orphan drugs, this means that PEG is unlikely to represent good value for money when considered against the current standards applied to interventions in the UK Health service.

\section{Conclusion}

PEG effectively reduces IGF-1 levels and improves signs and symptoms of acromegaly. Adverse events associated with treatment are of relatively minor severity and low prevalence, at least in the short term, and compliance is probably about $80 \%$. When considered against the norms currently used to determine cost-effectiveness within the UK, PEG does not represent good value for money. For PEG treatment to be more acceptable to commissioners special criteria appropriate to orphan drugs would need to be adopted or the cost of PEG reduced. 


\section{List of abbreviations}

GH: growth hormone; IGF-1: insulin like growth factor-1; PEG: pegvisomant; QALY: quality adjusted life year; LYG: life year gained; GHRH: growth hormone releasing hormone; DOPA: dopamine agonist; SSA: somatostatin agonist; LASSA: long acting SSA; RCT: randomised controlled trial; ICER: incremental cost-effectiveness ratio; MRI: magnetic resonance imaging; $\mathrm{CI}$ : confidence interval; SC: standard care; MM: manufacturer's model; WMP: Welsh Medicines Partnership; BNF: British National Formulary; NHS: National Health Service; QoL: quality of life; PD: perfect drug; SMR: standardised mortality ratio.

\section{Competing interests}

The authors declare that they have no competing interests.

\section{Authors' contributions}

DJM conceived and supervised the study, helped draft and edited the manuscript. YA developed the protocol, extracted data on effectiveness and helped design the search strategies. MJC synthesised the effectiveness evidence, modified and implemented the economic model and helped draft the manuscript. SB designed and implemented the search strategies. All authors have read and approved the final manuscript.

\section{Additional material}

\section{Additional file 1}

Search strategy details. Provides details of search strategies used to identify relevant research

Click here for file

[http://www.biomedcentral.com/content/supplementary/14726823-9-20-S1.PDF]

\section{Additional file 2}

Identification of effectiveness studies and list of excluded studies. Provides a flow diagram of the selection of reviewed evidence and details of studies/articles that did not meet all of the selection criteria

Click here for file

[http://www.biomedcentral.com/content/supplementary/14726823-9-20-S2.PDF]

\section{Additional file 3}

Main characteristics of the included publications. Provides details of the characteristics of the reviewed studies

Click here for file

[http://www.biomedcentral.com/content/supplementary/14726823-9-20-S3.PDF]

\section{Additional file 4}

Further details of included studies. Provides further details of the reviewed studies

Click here for file

[http://www.biomedcentral.com/content/supplementary/14726823-9-20-S4.PDF]

\section{Acknowledgements}

This research was in part supported by the West Midlands Primary Care Trusts' Levy, UK. We thank Pfizer UK Limited for open access to the manufacturer's economic model of cost-effectiveness of pegvisomant. We are indebted to Professor Paul Stewart and to Dr Andy Bates for their interest and expert clinical advice. We thank Dr Dechao Wang for advice and help with economic modelling.

\section{References}

I. Melmed S, Melmed S: Medical progress: Acromegaly. [Review] [102 refs]. New England Journal of Medicine 2006, 355:2558-2573.

2. Chanson P, Salenave S: Acromegaly. Orphanet J Rare Dis 2008, 3:17.

3. Colao A, Ferone D, Marzullo P, Lombardi G: Systemic complications of acromegaly: epidemiology, pathogenesis, and management. Endocr Rev 2004, 25:102-152.

4. Holdaway IM, Rajasoorya C: Epidemiology of acromegaly. Pituitary 1999, 2:29-41.

5. Pfizer Limited: Somavert: Summary of Product Characteristics. 2004 [http://emc.medicines.org.uk/medicine//4353/SPSOMA VERT $+10 \mathrm{mg} \% 2 \mathrm{c}+15 \mathrm{mg}+\% 26+20 \mathrm{mg}+$ powder+and + solvent+for+solution+for+injection/]. Accessed August 2007

6. NHS Centre for Reviews and Dissemination University of York Undertaking systematic reviews of research on effectiveness: CRDs guidance for those carrying out or commisioning reviews. 4. 2nd edition. 2001.

7. Trainer PJ, Drake WM, Katznelson L, Freda PU, Herman-Bonert V, Lely AJ van der, Dimaraki EV, Stewart PM, Friend KE, Vance ML: Treatment of acromegaly with the growth hormone-receptor antagonist pegvisomant. The New England journal of medicine 2000, 342: II7I- 1177.

8. Lely AJ van der, Hutson RK, Trainer PJ, Besser GM, Barkan AL, Katznelson L, Klibanski A, Herman-Bonert V, Melmed S, Vance ML: Long-term treatment of acromegaly with pegvisomant, a growth hormone receptor antagonist[see comment]. Lancet 200I, 358:1754-1759.

9. Sesmilo G, Fairfield WP, Katznelson L, Pulaski K, Freda PU, Bonert V, Dimaraki E, Stavrou S, Vance ML, Hayden D: Cardiovascular risk factors in acromegaly before and after normalization of serum IGF-I levels with the GH antagonist pegvisomant. The Journal of clinical endocrinology and metabolism 2002, 87:1692-1699.

10. Fairfield WP, Sesmilo G, Katznelson L, Pulaski K, Freda PU, Stavrou S, Kleinberg D, Klibanski A: Effects of a growth hormone receptor antagonist on bone markers in acromegaly. Clinical endocrinology 2002, 57:385-390.

II. Biering H, Saller B, Bauditz J, Pirlich M, Rudolph B, Johne A, Buchfelder M, Mann K, Droste M, Schreiber I: Elevated transaminases during medical treatment of acromegaly: a review of the German pegvisomant surveillance experience and a report of a patient with histologically proven chronic mild active hepatitis. European Journal of Endocrinology 2006, I 54:2I3-220.

12. Parkinson C, Burman P, Messig M, Trainer PJ, Parkinson C, Burman P, Messig M, Trainer PJ: Gender, body weight, disease activity, and previous radiotherapy influence the response to pegvisomant. Journal of Clinical Endocrinology \& Metabolism 2007, 92:190-195.

13. Paisley AN, O'Callaghan C], Lewandowski KC, Parkinson C, Roberts ME, Drake WM, Monson JP, Trainer PJ, Randeva HS, Paisley AN: Reductions of circulating matrix metalloproteinase 2 and vascular endothelial growth factor levels after treatment with pegvisomant in subjects with acromegaly. Journal of Clinical Endocrinology \& Metabolism 2006, 91 : 4635-4640.

14. Parkinson C, Flyvbjerg A, Trainer PJ: High levels of I50-kDa insulin-like growth factor binding protein three ternary complex in patients with acromegaly and the effect of pegvisomantinduced serum IGF-I normalization. Growth hormone \& IGF research: official journal of the Growth Hormone Research Society and the International IGF Research Society 2004, I4:59-65.

15. Parkinson C, Kassem M, Heickendorff L, Flyvbjerg A, Trainer PJ: Pegvisomant-induced serum insulin-like growth factor-I normalization in patients with acromegaly returns elevated markers of bone turnover to normal. The Journal of clinical endocrinology and metabolism 2003, 88:5650-5655.

16. Colao A, Pivonello R, Auriemma RS, De Martino MC, Bidlingmaier M, Briganti F, Tortora F, Burman P, Kourides IA, Strasburger C]: Effi- 
cacy of I 2-month treatment with the GH receptor antagonist pegvisomant in patients with acromegaly resistant to long-term, high-dose somatostatin analog treatment: effect on IGF-I levels, tumor mass, hypertension and glucose tolerance. European Journal of Endocrinology 2006, 154:467-477.

17. Jehle S, Reyes CM, Sundeen RE, Freda PU, Jehle S, Reyes CM, Sundeen RE, Freda PU: Alternate-day administration of pegvisomant maintains normal serum insulin-like growth factor-I levels in patients with acromegaly. Journal of Clinical Endocrinology \& Metabolism 2005, 90:1588-1593.

18. Feenstra J, de Herder WW, ten Have SM, Beld AW van den, Feelders RA, Janssen JA, Lely A van der, Feenstra J, de Herder WW, ten Have SMTH: Combined therapy with somatostatin analogues and weekly pegvisomant in active acromegaly[erratum appears in Lancet. 2005 May;365(947I): 1620]. Lancet 2005, 365: $1644-1646$

19. Jorgensen JO, Feldt-Rasmussen U, Frystyk J, Chen JW, Kristensen LO Hagen C, Orskov H, Jorgensen JOL, Feldt-Rasmussen U, Frystyk J: Cotreatment of acromegaly with a somatostatin analog and a growth hormone receptor antagonist. Journal of Clinical Endocrinology \& Metabolism 2005, 90:5627-563I.

20. Pivonello R, Galderisi M, Auriemma RS, De Martino MC, Galdiero M, Ciccarelli A, D'Errico A, Kourides I, Burman P, Lombardi G: Treatment with growth hormone receptor antagonist in acromegaly: effect on cardiac structure and performance. Journal of Clinical Endocrinology \& Metabolism 2007, 92:476-482.

21. Schreiber I, Buchfelder M, Droste M, Forssmann K, Mann K, Saller B, Strasburger C], the GPI, Schreiber I, Buchfelder M: Treatment of acromegaly with the $\mathbf{G H}$ receptor antagonist pegvisomant in clinical practice: safety and efficacy evaluation from the German Pegvisomant Observational Study. European Journal of Endocrinology 2007, I 56:75-82.

22. Parkinson C, Drake WM, Wieringa G, Yates AP, Besser GM, Trainer PJ, Parkinson C, Drake WM, Wieringa G, Yates AP: Serum lipoprotein changes following IGF-I normalization using a growth hormone receptor antagonist in acromegaly. Clinical Endocrinology 2002, 56:303-3II.

23. Parkinson C, Whatmore AJ, Yates AP, Drake WM, Brabant G, Clayton PE, Trainer PJ, Parkinson C, Whatmore AJ, Yates AP: The effect of pegvisomant-induced serum IGF-I normalization on serum leptin levels in patients with acromegaly. Clinical Endocrinology 2003, 59:168-174.

24. Barkan AL, Burman P, Clemmons DR, Drake WM, Gagel RF, Harris PE, Trainer PJ, Lely AJ van der, Vance ML: Glucose homeostasis and safety in patients with acromegaly converted from longacting octreotide to pegvisomant. The Journal of clinical endocrinology and metabolism 2005, 90:5684-5691.

25. Paisley AN, Hayden K, Ellis A, Anderson J, Wieringa G, Trainer PJ: Pegvisomant interference in $\mathbf{G H}$ assays results in underestimation of GH levels. European Journal of Endocrinology 2007, 156:315-319.

26. Welsh Medicines Partnership: Therapeutic Development Assessment Pegvisomant (Somavert ${ }^{\circledR}$ ). 2007 [http:// www.wales.nhs.uk/sites3/Documents/37l/ Enc\%203\%20WMP\%20Pegvisomant\%20report.pdf]. Accessed June 2007

27. Bates AS, Van't HW, Jones JM, Clayton RN: An audit of outcome of treatment in acromegaly. Q J Med 1993, 86:293-299.

28. Orme SM, McNally RJ, Cartwright RA, Belchetz PE: Mortality and cancer incidence in acromegaly: a retrospective cohort study. United Kingdom Acromegaly Study Group. J Clin Endocrinol Metab 1998, 83:2730-2734.

29. Kauppinen-Makelin R, Sane T, Reunanen A, Valimaki MJ, Niskanen L, Markkanen $\mathrm{H}$, Loyttyniemi E, Ebeling T, Jaatinen $\mathrm{P}$, Laine $\mathrm{H}$ : A nationwide survey of mortality in acromegaly. J Clin Endocrinol Metab 2005, 90:408I-4086

30. Ayuk J, Clayton RN, Holder G, Sheppard MC, Stewart PM, Bates AS: Growth hormone and pituitary radiotherapy, but not serum insulin-like growth factor-I concentrations, predict excess mortality in patients with acromegaly. I Clin Endocrinol Metab 2004, 89: $1613-1617$

31. Rowles SV, Prieto L, Badia X, Shalet SM, Webb SM, Trainer PJ: Quality of life (QOL) in patients with acromegaly is severely impaired: use of a novel measure of QOL: acromegaly quality of life questionnaire. J Clin Endocrinol Metab 2005, 90:3337-3341.
32. Kauppinen-Makelin R, Sane T, Sintonen H, Markkanen H, Valimaki MJ, Loyttyniemi E, Niskanen L, Reunanen A, Stenman UH, KauppinenMakelin R: Quality of life in treated patients with acromegaly. Journal of Clinical Endocrinology \& Metabolism 2006, 91:389|-3896.

33. Biermasz NR, van Thiel SW, Pereira AM, Hoftijzer HC, van Hemert AM, Smit JW, Romijn JA, Roelfsema F: Decreased quality of life in patients with acromegaly despite long-term cure of growth hormone excess. J Clin Endocrinol Metab 2004, 89:5369-5376.

34. Hua SC, Yan YH, Chang TC, Hua SC, Yan YH, Chang TC: Associations of remission status and lanreotide treatment with quality of life in patients with treated acromegaly. European Journal of Endocrinology 2006, 155:83|-837.

35. Webb SM, Badia X, Surinach NL, Spanish AcroQol Study Group: Validity and clinical applicability of the acromegaly quality of life questionnaire, AcroQoL: a 6-month prospective study. European Journal of Endocrinology 2006, 155:269-277.

36. Trepp R, Everts R, Stettler C, Fischli S, Allemann S, Webb SM, Christ ER: Assessment of quality of life in patients with uncontrolled vs. controlled acromegaly using the Acromegaly Quality of Life Questionnaire (AcroQoL). Clin Endocrinol (Oxf) 2005, 63:103-110.

37. British National Formulary: 2007 [http://www.bnf.org/bnf/]. Accessed June 2007

38. NHS reference costs 2005-06, Mental Health Services: Inpatient Data. MHIPA2 adult: acute care 2007. Ref Type: Data File

39. Moore D, Meads C, Roberts L, Song F: The effectiveness of somatostatin analogues in the treatment of acromegaly. Report 37, West Midlands Health Technology Assessment Collaboration. Department of Public Health \& Epidemiology, University of Birmingham 200I:I-74. Ref Type: Report

40. Cambridgeshire joint prescribing group decision document: Pegvisomant (Somavert, Pfizer) for treatment of acromegaly. 2006 [http://www.cambsphn.nhs.uk/docu mentC|PG\%20InformatioDecisionPegvisomant\%2\%20Decision\%20]a n\%202006.doc?pre ventCache $=08 \% 2 \mathrm{FI} \% 2 \mathrm{~F} 2006+16 \% 3 \mathrm{AI}$ ] $]$. Accessed June 2007

4l. Didoni G, Grottol S, Gasco V, Battistini M, Ferone D, Giusti M, Ragazzoni $F$, Ruffo $P$, Ghigo $E$, Minuto $F$ : Cost-of-illness study in acromegalic patients in Italy. J Endocrinol Invest 2004, 27:1034-1039.

42. Bonert VS, Kennedy L, Petersenn S, Barkan A, Carmichael J, Melmed $\mathrm{S}$ : Lipodystrophy in patients with acromegaly receiving pegvisomant. J Clin Endocrinol Metab 2008, 93:35I5-35I8.

\section{Pre-publication history}

The pre-publication history for this paper can be accessed here:

http://www.biomedcentral.com/1472-6823/9/20/prepub

Publish with BioMed Central and every scientist can read your work free of charge

"BioMed Central will be the most significant development for disseminating the results of biomedical research in our lifetime. "

Sir Paul Nurse, Cancer Research UK

Your research papers will be:

- available free of charge to the entire biomedical community

- peer reviewed and published immediately upon acceptance

- cited in PubMed and archived on PubMed Central

- yours - you keep the copyright

Submit your manuscript here:

http://www.biomedcentral.com/info/publishing_adv.asp

BiolMedcentral 